\title{
User Acceptance Study on Academic Information System in University XYZ
}

\author{
Darmawan Napitupulu \\ Research Center for Quality System and Testing \\ Technology \\ Indonesian Institute of Sciences \\ Tangerang Selatan, Indonesia \\ darmawan.baginda.napitupulu@lipi.go.id \\ Rahmi Kartika Jati \\ Research Center for Quality System and Testing \\ Technology \\ Indonesian Institute of Sciences \\ Tangerang Selatan, Indonesia \\ rahmi.kartika.jati@lipi.go.id \\ Janner Simarmata \\ State University of Medan \\ Medan, Indonesia \\ jannersimarmata@unimed.ac.id \\ Leon Andretti Abdillah \\ Departement of Information Systems \\ Universitas Bina Darma \\ Palembang, Indonesia \\ leon.abdillah@yahoo.com \\ Muhammad Ikhsan Setiawan \\ Narotama University, Indonesia \\ Ikhsan.setiawan@narotama.ac.id
}

\author{
Ansari Saleh Ahmar \\ Departement of Statistics \\ Universitas Negeri Makassar \\ Makassar, Indonesia \\ ansarisaleh@unm.ac.id
}

\author{
Robbi Rahim \\ School of Computer and Communication Engineering \\ Universiti Malaysia Perlis \\ usurobbi85@zoho.com
}

Heri Nurdiyanto

Informatics Engineering Departement

STMIK Dharma Wacana

Lampung, Indonesia

herinurdiyanto@gmail.com

Wahyuddin Albra

Departement of Accounting

Universitas Malikussaleh

Aceh, Indonesia

wahyudin@unimal.ac.id

Dahlan Abdullah

Department of Informatics

Universitas Malikussaleh

Aceh, Indonesia

dahlan@unimal.ac.id

\author{
Rahmat Hidayat \\ Department of Information Technology \\ Politeknik Negeri Padang \\ Padang, Indonesia \\ rahmat@polinpdg.ac.id
}

Cut Ita Erliana

Departement of Industrial

Universitas Malikussaleh

Aceh, Indonesia

cutitha@unimal.ac.id

\begin{abstract}
Impact advancement of Information Technology and Communication (ICT) has changed the work culture of the organization including universities. The management of the academic process in higher education becomes very important because the core competencies that must be owned for ensuring the quality of education provided. ICT is believed to be able to provide support in managing academic processes effectively and efficiently, one through the existence of academic information systems has become a necessity for college and even academic
\end{abstract}

information system that was developed to reflect the quality of the management of a college. Implementation of academic information systems at XYZ University has been running more than 5 (five) years but had never done an evaluation related to user acceptance. This study aimed to evaluate the extent of the environmental acceptability of the user in the organization with the approach of TAM (Technology Acceptance Model). The results showed the perceived ease of use (perceived ease of use) and usefulness (perceived usefulness) positive significant effect on 
the interest the usage behavior (behavioral intention) where the perceived ease of use is more dominant than the perception of usefulness.

Keywords-academic information system; user acceptance; ease of use; usefulness; TAM

\section{INTRODUCTION}

Impact of advances in Information and Communication Technology (ICT) has changed the work culture of organizations including universities. The management of academic process in universities becomes very important because it is the core competence that must be owned to guarantee the quality of education provided. The utilization and integration of ICT in the academic process is believed to improve the effectiveness and efficiency of the academic process itself [10]. In order to improve the quality of education, ICT has proven able to provide support in managing academic process effectively and efficiently [7,15]. Academic information system has become a necessity for universities and even academic information system developed can reflect the quality of management of a college.

University must have an information system prepared to support the management and improvement of academic program quality. The information system of a university consists of data collection, analysis, storage, retrieval, presentation of data and information as well as communication with interested parties that are built centrally at the university level known as integrated information system. In other words can be said systematic academic information systematic, accurate, valid, effective, and efficient indicate that the college is managed professionally. Assessment of good and bad an academic information system provided by users (students, lecturers, education personnel).

Implementation of academic information system at XYZ University has been running for more than 5 (five) years but has not been evaluated related to user acceptance of academic information system that has been implemented. User acceptance becomes very important to support the success of a technology or information system. This is because acceptability can predict the utilization rate of the technology in the future [1]. If the utilization rate is high then it is said that the technology or information system implemented has been successful $[3,17,18]$. Academic information systems provide information and services to users, especially students in order to assist the academic process and lectures for all academic community. Information and services provided ranging from academic registration (KRS), financial registration, guardianship, scheduling courses, scholarships and study cards (KHS). Feature found in siakad felt can overcome various problems that happened before in college especially about student academic activity. For example before there is online registration of KRS, students have difficulties in registering because they have to come to the campus and meet the guardian lecturer to ask for approval. With siakad, students can perform KRS academic registration easily and quickly. It also improves student discipline on charging KRS which can only be done at certain period of time. If students are late or negligent in the process of academic registration will be subject to sanctions such as academic leave, etc.

The largest users of academic information systems are students, so the largest data that is also used as an evaluation material is students. Students have a high level of intellectuality and curiosity and tend not to be afraid to try new things including trying technology (academic information system). They also have the knowledge and willingness to learn to use technology. Based on the explanation, the students should have no difficulty in receiving academic information system, especially at XYZ University.

Assessment of user acceptance of academic information system is necessary because the technology without accompanying user acceptance will cause the utilization rate will be low [1].

These conditions lead to information and communication technology will not provide benefits, but instead even lead to inefficiency, disintegration, and complexity, both at the individual level or organizational level. In addition, academic information system that high acceptance of course can provide quality services to users (students) which in turn have an impact on increasing the value of the organization. The acceptance of users of academic information systems can be used as an evaluation of the implementation of ICT is able to provide more value for the organization or vice versa.

Thus this study aims to evaluate the extent to which user's acceptance of academic information system (SIAKAD) is implemented. The evaluation results can be input and recommendations for the organization to improve the quality of its services based on technology.

\section{THEORY}

\section{A. TAM (Technology Acceptance Model)}

Technology Acceptance Model (TAM) is a model used to measure the extent to which the level of user acceptance of a technology, especially information technology. The TAM model was originally developed by Davis (1989) based on the TRA (Theory of Reasoned Action) model to cover gaps that explain factors that influence or encourage users using technology. In his research, Davis (1989) proposed two key factors of user behavior of technology on the acceptance or adoption of the technology. The two key factors are ease of use and usefulness, both of which are believed to predict attitudes or behavior in using technology. In other words, the two factors simultaneously affect the desire to use and then affect the use of the system or technology [6]. Based on the results of research conducted Davis (1989), the two factors or variables are proven to significantly affect user acceptance of technology. It is also supported by many other studies or studies where empirically it has been proved its validity $[2,12,13,14]$. In other words the TAM model has been tested can measure the acceptance of technology based on the persepi users.

The TAM model becomes the basis for evaluation of user behavior in using technology that can be presented in Figure 1. 


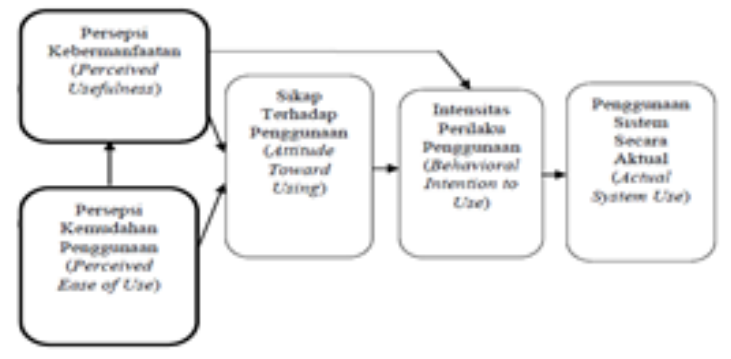

Fig. 1. Technology Acceptance Model (Davis, 1989)

Based on Figure 1 above, it can be seen that technology users will have an interest in using technology (interest in behavior) if they feel the system or technology is useful and easy to use. TAM believes that the use of technology can improve the performance of a person or organization, and provide convenience for users in completing their work [5]. In other words the cause of rejection by technology users can be predicted from these factors. If you see the TAM model above there are five pieces of constructs or variables consisting of:

\section{1) Perceived usefulness.}

Perceived usefulness is defined as the extent to which a person believes that using a technology will improve the performance of his work [6,11]. From this definition, it is known that perceived usefulness (belief) is a belief (belief) about the decision-making process. Thus if one feels confident that a technology is useful then he will use it. Conversely, if one believes that a technology is less useful then he will not use it.

\section{2) Perceived ease of use.}

Perceived ease of use is defined as the extent to which a person believes that using a technology will be free of effort $[6,11]$. From the definition, it is known that perceived ease of use is also a belief (belief) about the decision-making process where one feels confident that a technology is easy to use then he will use it. Conversely, if one believes that a technology is not easy to use then he will not use it.

\section{3) Attitude towards using technology.}

Attitudes toward behavior are defined by Davis et al. (1989) as the positive or negative feelings of a person if they have to perform the behavior to be determined. Attitudes toward behavior are also defined by Mathieson (1991) as a user evaluation of the relevance of using the system [11].

\section{4) Behavioral intention to use.}

Behavioral intention is a desire of someone to perform a certain behavior. Someone will do a behaviour if they have a desire or intention to do so [16].

\section{5) Actual system use.}

Behavior is an action performed by a person. In the context of the use of technology systems, behavior is the actual use of technology [16].

\section{STATE OF THE ART}

The technology acceptance model (TAM) is a model that has been used extensively in various domains such as business, government to education that utilize information technology in its business processes. In the field of education, there are already a number of researchers who use TAM to explain user acceptance of technologies such as e-learning, multimedia learning technologies, digital libraries, e-journals and even academic information systems.

For the case of e-learning, research conducted by Park (2009) on a number of university students in Korea related interest in using e-learning. The results of his research membahikan that TAM is a suitable theory to understand the acceptance of e-learning users. The two variables ie ease of use (ease of use) and usefulness (influenceness) have a significant effect on student interest using (behavioral intention to use) elearning. In addition there are other studies that use TAM in the context of e-learning [1,4].

In addition to e-learning, TAM utilization is also applied to the development of multimedia learning technologies such as those conducted by Syafrizal (2015) and Wijaya (206). In research Wijaya (2016), conducted a study of user acceptance of Google technology (Google Clasroom) on STT Musi Palembang. The result of the research shows perception of ease of use and perception of goodness individually and together have significant effect on the use of Google Classroom.

In the context of digital libraries and e-journals, some researchers have also used the TAM model to examine factors affecting user acceptance of digital libraries (Thong, 2004; Kim, 2005). According to Thong (2004), one's acceptance of digital library technology influences its utilization rate in the future.

While in the context of academic information system (siakad) as did Riskadewi (2007) who look for picture of academic information system of Universitas Airlangga Cyber Campus (UACC) from FISIP lecturer perspective of Airlangga University. The results showed descriptively, UACC academic information system can be accepted by lecturers to support the process of learning activities. Still the lack of user acceptance study especially in academic information system application hence this research aim to perform measurement of user acceptance to academic information system (SIAKAD) at XYZ University in order to evaluate its utilization in organization environment.

\section{METHOD}

This research is a correlational research, which according to Gay (in Sukardi, 2008: 165) is a study with data collection to determine the relationship and level of relationship between two variables or more. The method of collecting data in this study is a survey based on questionnaires to measure user acceptance of academic information system in XYZ University so that can know the correlation between perceived ease of use and perceptions of usefulness with interest in the use of SIAKAD behavior. The questionnaire was designed with TAM (Technology Acceptance Model) approach and distributed to 150 respondents selected by purposive sampling. Respondent 
in this research is student in XYZ university with criterion at least in semester 2 (two) because assumed the respondent have used academic information system (SIAKAD) for example for academic registration, course schedule information, study result card, etc.

Respondents were asked to give their level of agreement to any statement regarding user acceptance to academic information system consisting of 4 Likert scales ie $1=$ "strongly disagree", 2 = "disagree", 3 = "agree" and $4=$ "strongly agree".

The TAM model as mentioned previously consists of five constructs: perception of ease of use, perception of expediency, attitudes toward usage, interest in usage behavior and actual system usage [6]. But over time TAM models are widely used and developed by other researchers. Gahtani (2001) modified the TAM model by combining the behavior interest interest variable with the actual use of the system into the acceptance variable. Therefore in this study TAM model that will be studied following [8] is as follows:

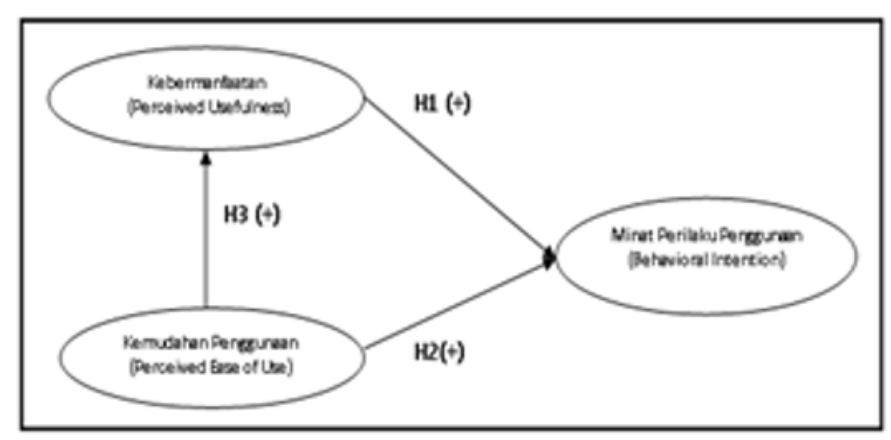

Fig. 2. Research Model

Based on the above research model then there are several hypotheses to be tested are:

H1: Perceived usefulness has a significant positive effect on behavioral intention.

H2: Perceived ease of use has a significant positive effect on behavioral intention.

H3: Perceived ease of use has a significant positive effect on perceived usefulness.

H4: Perceived usefulness and perceived ease of use together have a significant effect on behavioral intention.

The TAM model in this study consists of two independent variables namely perceived usefulness and perceived ease of use and one dependent variable namely acceptance. Perceived usefulness has 6 indicators of measurement, perceived ease of use also consists of 6 indicators while the acceptance variable has 4 indicators which can be seen in Table I as follows:
TABLE I.

OPERATIONAL VARIABLES OF TAM RESEARCH

\begin{tabular}{|l|l|l|}
\hline No & Variables & Indicators \\
\hline 1 & Perceived Usefulness (X1) & Work Accelerate (X1.1) \\
\hline & & Performance Accelerate (X1.2) \\
\hline & & Productivity Increase (X1.3) \\
\hline & & Effectiveness (X1.4) \\
\hline & & Berk Simplify (X1.5) \\
\hline 2 & Perceived Ease of Use (X2) & Easy to Learn (X2.1) \\
\hline & & Controlled (X2.2) \\
\hline & & Clear and Understandable (X2.3) \\
\hline & & Flexibility (X2.4) \\
\hline & & Easy to be Skilled (X2.5) \\
\hline 3 & Behavioral Intention (Y1) & Use Motivation (Y1.1) \\
\hline & & $\begin{array}{l}\text { Addition of IT Support Software } \\
\text { (Y1.2) }\end{array}$ \\
\hline & & Encouraging Other Users (Y1.3) \\
\hline
\end{tabular}

Hypothesis testing in this study using multiple linear regression analysis with the help of SPSS tool to process data from respondents who provide an assessment of the questionnaire in Likert scale. The general equation of multiple linear regression can be presented as follows:

$$
Y=\mathrm{a}+\mathrm{b} 1 \mathrm{X} 1+\mathrm{b} 2 \mathrm{X} 2+\mathrm{e}
$$

Where, $\mathrm{Y}$ is Acceptance (acceptance); a is Direct relation of independent and bound variable; b1 is Perceived usefulness towards perceived behavior; b2 is Perceived ease of use against behavioral interests; e is Residue error

The purpose of multiple linear regression technique is to estimate the magnitude of parameters a, b1 and b2 as regression coefficients of the above research model [9].

\section{RESULTS AND DISCUSSION}

\section{A. Instrument Validity and Reliability}

At the data collection stage, the questionnaire was distributed to 168 respondents but there were only 150 questionnaires that could be used for the analysis phase. This is because there are some incomplete data or missing data in the questionnaire filling. Thus only complete questionnaire data were used in this study. Before the questionnaire data is processed and analyzed, the validity and reliability of the instrument must be tested first to test the instrument used has been feasible and meets the specified requirements.

The results of validity test questionnaire in this study can be seen from the coefficient of validity of the instrument that is the value of rhitung (corrected item-total correlation), where if rhitung larger than rtabel then the indicator (statement) is said valid [3] which can be presented in Table II Test Results Validity of the following Instruments.

Based on the Table II can be seen that each indicator / item of measurement has a value rhitung greater than rtabel $(0.3)$. Thus the overall indicator or item of measurement can be said to be valid because it has met the requirements $(>0.3)$. 
TABLE II. INSTRUMENT VALIDITY TESTING RESUlTS

\begin{tabular}{|l|l|l|l|}
\hline No & Indicators & $\begin{array}{l}\text { Corrected Item- } \\
\text { Total Correlation } \\
\text { (result) }\end{array}$ & Explanation \\
\hline \multicolumn{3}{|l|}{ Perceived Usefulness (X1) } & Valid \\
\hline 1 & Work Accelerate (X1.1) & 0.376 & Valid \\
\hline 2 & $\begin{array}{l}\text { Performance Accelerate } \\
\text { (X1.2) }\end{array}$ & 0.435 & Valid \\
\hline 3 & Productivity Increase (X1.3) & 0.577 & Valid \\
\hline 4 & Effectiveness (X1.4) & 0.620 & Valid \\
\hline 5 & Work Simplify (X1.5) & 0.603 & Valid \\
\hline 6 & Beneficial (X1.6) & 0.590 & Valid \\
\hline Perceived Ease of Use (X2) & 0.508 & Valid \\
\hline 1 & Easy to Learn (X2.1) & 0.577 & Valid \\
\hline 2 & Controlled (X2.2) & Valid \\
\hline 3 & $\begin{array}{l}\text { Clear and Understandable } \\
\text { (X2.3) }\end{array}$ & 0.461 & Valid \\
\hline 4 & Flexibility (X2.4) & 0.641 & Valid \\
\hline 5 & Easy to be Skilled (X2.5) & 0.636 & Valid \\
\hline 6 & Easy to Use (X2.6) & 0.510 & Valid \\
\hline Behavioral Intention (Y1) & Use Motivation (Y1.1) & 0.588 & Valid \\
\hline 1 & Addition of IT Support & 0.583 & \\
\hline 2 & Software (Y1.2) & $\begin{array}{l}\mid \\
\text { (Y1.3) }\end{array}$ \\
\hline 3 & Encouraing Other Users & 0.611 & \\
\hline
\end{tabular}

Reliability testing questionnaire in this study was conducted with cronbach alpha on each variable. According Ghozali (2002), cronbach alpha technique is a technique that will show the index of internal consistency that is accurate, fast, and economical. The instrument is said to meet reliability if the value of cronbach alpha is greater than 0.60 . Reliability test results of the questionnaire can be presented in Table III as follows.

TABLE III. INSTRUMENT RELIABILITY TEST RESUlTS

\begin{tabular}{|l|l|l|}
\hline No & Variables & Cronbach Alpha \\
\hline 1 & Perceived Usefulness (X1) & 0.795 \\
\hline 2 & Perceived Ease of Use (X2) & 0.786 \\
\hline 3 & Behavioral Intention (Y1) & 0.749 \\
\hline
\end{tabular}

Based on Table III it can be shown that each research variable is acceptance, perception of usability and perception of ease of use meet the reliable element. This is evidenced by the value of Cronbach alpha as reliability coefficient for behavioral intention interest variable of 0.749 , perceived usefulness of 0.786 and perceived ease of use of 0.795 . Overall, the reliability coefficient obtained is 0.889 . The results of Cronbach alpha is greater than 0.60 as a condition that the instrument can be said reliable. Thus the instrument in this study is valid and reliable because it meets the minimum requirements.

\section{B. Hypothesis testing}

Hypothesis testing in this research is done by multiple regression analysis which aims to know the influence of two independent variables of research, perceived ease of use and perceived usefulness to dependent variable that is behavioral interest of use (behavioral intention).
In this study there are five hypotheses tested first, whether perceived usefulness (influence perceived usefulness) influence significant positive effect on behavioral interest of use (behavioral intention); second, whether perceived ease of use has a significant positive effect on behavioral intention; third, whether perceived ease of use has a significant positive effect on perceived usefulness and fourth, whether perceived usefulness and perceived ease of use have a significant effect simultaneously on interest in behavioral use (behavioral intention).

TABLE IV. INDIVIDUAL SIGNIFICANCE TEST RESUlts (T TEST)

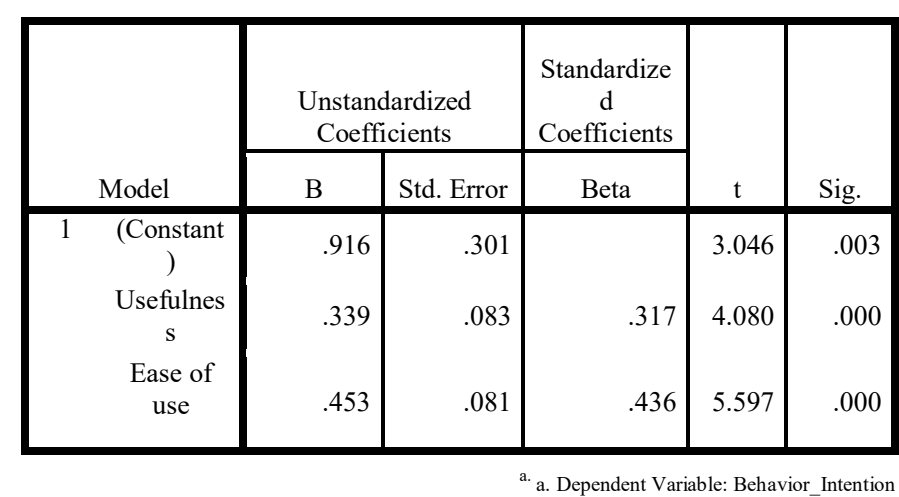

Based on Table IV can be generated multiple linear regression equation that is:

$$
\mathrm{Y}=0.916+0.339 \mathrm{X} 1+0.453 \mathrm{X} 2
$$

The multiple linear regression equation can be concluded the relationship between independent variable and dependent variable that is perceived usefulness variable has positive regression coefficient equal to 0339 . This means that perceived usefulness is directly proportional to behavioral intention. In other words, if the benefits of perceived technology are high then interest in usage behavior will be high as well. Meanwhile, the ease of use variable (perceived ease of use) also has a positive regression coefficient of 0.453 . This means that perceived ease of use is also directly proportional with behavioral interest in use (behavioral intention). In other words, if the perceived technology is easier to use then the interest in the use behavior will also be high against the technology. When compared to the regression coefficients of the two independent variables i.e. perceived ease of use and perceived usefulness, it can be said that the more dominant variable of influence on user acceptance is perceived ease of use.

In addition, in Table IV above, we can show the results of the individual significance test $(\mathrm{t}$ test) that the probability significance for the perceived usefulness variable is 0.000 $(<0.05)$ and the tcount is $4,080(>$ ttable $)$. This means that the first hypothesis (H1) is acceptable, that perceived usefulness has a significant positive effect on behavioral intention. The results of this study indicate that the existing academic information system (SIAKAD) is very useful in supporting the smoothness of the study of respondents and the success of teaching and learning process such as academic registration, financial registration, guardianship, scheduling courses, 
scholarships to assessment. Students who will attend the lecture must register academic, financial and guardianship before the relevant member is declared active. Therefore, academic information system is perceived as beneficial by the respondents because the academic preparation process must be done through academic information system (sia SIAKAD kad). For perceived ease of use variable has probability significance $0.000(<0.05)$ and tcount price is $5.597(<t$ tabel). This means that the second hypothesis $(\mathrm{H} 2)$ can be supported that perceived ease of use has a significant effect on behavioral intention because it meets the requirements. The results of the analysis show academic information system (SIAKAD) in the university is also considered easy to be studied and operated by the respondents. Web-based SIAKAD is very familiar to use by students, plus the socialization held by the university to provide knowledge and skills to the user so that students more easily become skilled in using the application.

To test the third hypothesis (H3), a second individual significance test ( $t$ test) is used perceived ease of use for perceived usefulness which can be presented in Table V.

TABLE V. INDIVIDUAL SIGNIFICANCE TEST RESUlts (T TEST) REGRESSION MODEL 2

\begin{tabular}{|c|c|c|c|c|c|}
\hline \multirow[b]{2}{*}{ Model } & \multicolumn{2}{|c|}{$\begin{array}{c}\text { Unstandardized } \\
\text { Coefficients }\end{array}$} & \multirow{2}{*}{\begin{tabular}{|c|}
$\begin{array}{c}\text { Standardized } \\
\text { Coefficients }\end{array}$ \\
Beta \\
\end{tabular}} & \multirow[b]{2}{*}{$t$} & \multirow[b]{2}{*}{ Sig. } \\
\hline & $\mathrm{B}$ & $\begin{array}{l}\text { Std. } \\
\text { Error }\end{array}$ & & & \\
\hline \multirow[t]{2}{*}{1 (Constant) } & 1.760 & .260 & & 6.762 & .000 \\
\hline & .616 & .062 & .632 & 9.916 & .000 \\
\hline
\end{tabular}

b. a. Dependent Variable: Benefit

Based on Table $\mathrm{V}$ can be seen that perceived ease of use variables significantly and positively influence perceived usefulness (perceived usefulness). This can be shown with a probability value of significance of $0.000 \quad(<0.05)$ and regression coefficient 0.616 (positive). This is in line with Davis's research (1989) where perceived ease of use will affect perceived usefulness. Benefit according to Davis (1989) is consideration of profit (benefits) and cost (cost) in using the system. Ease of use can be seen as part of cost (cost) based on user perspective. Therefore, if the system is considered easy by the user, it means the cost (cost) or effort of use in using the system can be said to be low so it will also determine its usefulness (perceived usefulness).

The fourth hypothesis test (H4) is done through simultaneous significance test (F test) to find out whether all independent variables simultaneously affect the dependent variable that is behavioral interest of use (behavioral intention).

Based on Table VI it can be seen that the probability of significance is obtained at $0.000(<0.05)$ and the Fcount is 69.931. Thus it can be concluded that the fourth hypothesis (H4) is acceptable i.e. perceived usefulness variables (perceived usefulness) and perceived ease of use have a significant effect on behavioral intention interest (behavioral intention) together.

TABLE VI. SimultaneOUS SignificANCE TeSt Result (UJI F) ANOVAA

\begin{tabular}{|l|r|r|r|c|c|}
\hline Model & $\begin{array}{c}\text { Sum of } \\
\text { Squares }\end{array}$ & df & $\begin{array}{r}\text { Mean } \\
\text { Square }\end{array}$ & F & Sig. \\
\hline 1 Regression & 19.258 & 2 & 9.629 & 63.931 & $.000^{\mathrm{b}}$ \\
Residual & 22.141 & 147 & .151 & & \\
Total & 41.399 & 149 & & & \\
\hline
\end{tabular}

${ }^{c}$. Dependent Variable: Interests__Behavior

d. Predictors: (Constant), Convenience, Utility.

Then the last seen how much the contribution of independent variables in this study can explain the variation of the dependent variable that is behavioral interest in use (behavioral intention) which can be presented in Table VII.

TABLE VII. COEFFICIENT DETERMINATION TEST RESULTS

\begin{tabular}{|l|c|r|r|c|}
\hline Model & $\mathrm{R}$ & $\begin{array}{c}\mathrm{R} \\
\text { Square }\end{array}$ & $\begin{array}{c}\text { Adjusted } \\
\text { R Square }\end{array}$ & $\begin{array}{c}\text { Std. Error } \\
\text { of the } \\
\text { Estimate }\end{array}$ \\
\hline 1 & $.682^{\mathrm{a}}$ & .465 & .458 & .38810 \\
\hline
\end{tabular}

\section{CONCLUSION}

Based on the research that has been done can be drawn some conclusions as follows:

1. Perceived usefulness has a significant and positive effect on behavioral intention. It is shown from result of $t$ test with significance 0.000 with regression coefficient equal to 0339 .

2. Perceived ease of use has a significant and positive effect on behavioral intention. It can be shown from result of $t$ test with significance 0.000 with regression coefficient equal to 0453 .

3. Perceived ease of use has a significant positive effect on perceived usefulness. It can be shown from the result of $t$ test with significance 0.000 with regression coefficient value that is equal to 0.616 .

4. Perceived usefulness (perceived usefulness) and perceived ease of use together significantly influence behavioral interest intention (behavioral intention).

5. Interest in behavioral use (behavioral intention) can be explained by perceived usefulness (perceived usefulness) and ease of use (perceived ease of use) of $45.8 \%$. Thus the remaining $54.2 \%$ is influenced by other variables outside the model. 


\section{REFERENCES}

[1] Alharbi, S., \& Drew, S. 2014. Using the Technology Acceptance Model in Understanding Academics' Behavioural Intention to Use Learning Management Systems. International Journal of Advanced Computer Science and Applications, 5(1), pp: 143-155.

[2] Al-Busaidi, K., \& Al-Shihi, H. 2010. Instructors Acceptance of Learning Management Systems: A Theoretical Framework. Communications of the IBIMA.

[3] Azwar, S. 2012. Reliabilitas and Validity. Yogyakarta: Pustaka Pelajar.

[4] Dalimunthe, N., \& Wibisono, H. 2013. Jurnal Sains, Teknologi dan Industri. 11(1).

[5] Dasgupta, Subhasih, Mary, G., \& Nina, M. 2002. User Acceptance of ECollaboration Technology: An Extension of the Technology Acceptance Model. Group Decision and Negotiation, 11(2), pp: 87-100.

[6] Davis, F. D. 1989. Perceived Usefulness, Perceived Ease of Use, and User Acceptance of Information Technology. MIS Quarterly, 13(3), pp: 319-339.

[7] Delone, W.H., \& Mcean, E.R. 2003. The DeLone and McLean Model of Information Systems Success: A Ten- Year Update. Journal of Management Information Systems 19(4), pp: 9 - 30.

[8] Gahtani, S.A. 2001. The Applicability of TAM Outside North America: An Empirical Test in United Kingdom. Information Resource Management Journal, pp: 37-46.

[9] Ghozali, I. 2002. Application of Multivariate Analysis with SPSS Program ". Publishing Agency of Diponegoro University, Semarang, edition 2.

[10] Helianak, A.S., \& Surjono, H.D. 2014. Development of e-Learning Information and Communication Technology (ICT) Course at SMA Negeri 3 Kupang. Journal of Educational Technology Innovation, 1 (1), pp: 1-14.
[11] Jogiyanto, H.M. 2008. Information systems keperilakuan. Revised Edition. Publisher ANDI Offset Yogyakarta. Kim, D., \& Chang, H. 2007. Keywords: functional characteristics in designing and operating health information websites for user satisfaction: An application of the extended technology acceptance model. International Journal of Medical Informatics, 76, pp: 790-800.

[12] Kim, J. 2005. User acceptance of web-based subscription database. Dissertation of Doctor, Tallahassee Florida: Information Studies Department Florida State University.

[13] Ma, Q., \& Liu, L. 2004. The technology acceptance model: a metaanalysis of empirical findings. Journal of Organizational and End User Computing (JOEUC), 16, pp. 59-72.

[14] Moon, J., \& Kim, Y. 2001. Extending the TAM for a World-Wide-Web context. Information \& Management, 38, pp: 217-230.

[15] Napitupulu, D. 2016. Evaluate the quality of XYZ university website with Webqual approach. Bulletin of Posts and Telecommunications, 14 (1), pp: 51-64.

[16] Park, S.Y. 2009. An Analysis of the Technology Acceptance Model ini Understanding University Students' Behavioral Intention to Use e-Learning. Educational Technology \& Society, Vol.12, No. 3, pp: 150-162.

[17] Thong, J.Y.L., Wong, W., \& Tam, K.Y. 2004. Determinants of user acceptance of digital libraries: An Empirical Examination of Individual Differences and System Characteristics. Journal of Management Information Systems, 18(3).

[18] Wijaya, A. 2016. Analysis of Factors Affecting the Use of Google Classroom to Support Lectures. The 5th ICIBA 2016, International Conference on Information Technology and Engineering Application, pp:61-68. 